\title{
Contribution of the Airborne Magnetic Field to the Structural Study of the Variscan Granitoid of Rehamna, Morocco
}

\author{
Kawtar Benyas ${ }^{1, *}$, Abdellatif Aarab ${ }^{1}$, Abdellah Lakhloufi ${ }^{1}$, Abdelmounim Qarbous ${ }^{2}$, Ahmed Manar ${ }^{3}$, \\ Mounir Amar ${ }^{4}$, Assia Idrissi ${ }^{5}$ and Mohamed Elmimouni ${ }^{1}$

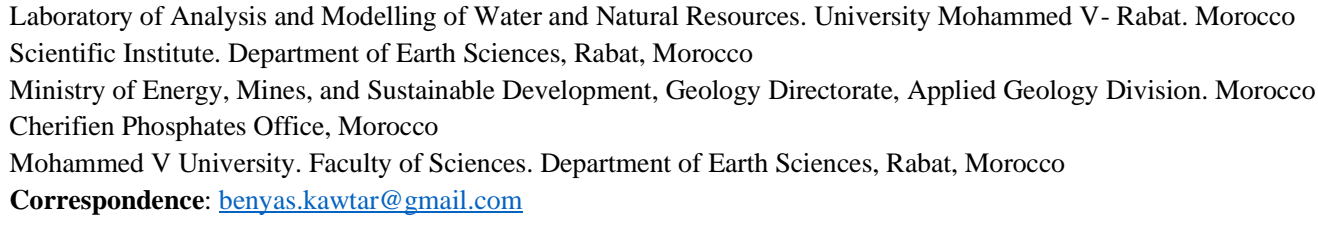

Received:

23 October 2021

\section{Abstract}

At the Moroccan Western Meseta, the study of airborne magnetic data from the Rehamna massif, using the potential aeromagnetic methods, has allowed us to improve and describe the geometry of the geological structures of the Rehamna variscan granitoids and their subsurface

Accepted:

10 November 2021 components. These methods have proven to be an adequate geophysical technique to study the deep and subsurface structures of this area covered by a thick Mesozoic-Cenozoic sedimentary

Published:

31 January 2022 cover. The calculation of the reduced map to pole and upward continuation of the reduced residual magnetic field to the pole at $2 \mathrm{~km}$ to $30 \mathrm{~km}$ shows the close relationship between the positive anomalies and the deep magma bodies that outcrop locally in the tectonic contacts; thus, a strong correlation between the aeromagnetic lineaments and the regional crustal-scale faults-oriented N-S to NE-SW. The calculation of the Euler deconvolution of these lineaments, using the different structural indices, shows a depth of aeromagnetic lineaments about ten kilometers due to the presence of a very thick sedimentary layer. The final structural map reveals four groups of faults oriented, respectively NNW-SSE, N-S, NNE-SSW, NE-SW, and E-W.

Keywords: Geophysics; Airborne magnetic field; Structural geology; Variscan granitoid; Rehamna; Morocco

\section{Introduction}

The Moroccan Western Meseta is characterized by the outcrop of numbers of Hercynian massifs (Central massif, Rehamna massif, and Jbilet massif). That lie discordantly on a Neoproterozoic basement (Baudin et al., 2003; Corsini et al., 1988; Letsch et al., 2018) and overlain by a Meso-Cenozoic cover (Fig. 1). The stratigraphic and tectonic correlation between these massifs is established by following Bordonaro's work et al. (1979); Destombes et al. (1982); Hollard et al. (1982); Mayol and Muller (1985). Classical surface geological studies of the Variscan granitoid of the Rehamna hercynian massif generally show poor exploitable mineralization, despite its hercynian context and geological similarities with nearest-neighbor hercynian domains with mining potential. In contrast, the Jbilet massif, just to the south, is one of the massifs with essential mineral deposits with a

DOI: $10.46717 /$ igj.55.1A.2Ms-2022-01-21 
well-developed economic power (Silver, Copper, Iron oxide, Sulphur, Zinc, Lead...). These deposits are generally found in lenticular form along N-S to E-W oriented accidents (Yahyaoui and Essaifi, 2011; Nshimiyimana et al., 2018). As for the Rehamna massif, similar alignments (faults, veins, magmatic bodies) outcrop at the surface, almost in the same directions as in the Jbilet massif, with the predominance of the NNE-SSW to NE-SW directions (Benyas et al., 2021); and show mineralization showings that may be exploitable, as well as the Eastern Rehamna, where a mineralized vein system (Tungsten, Lead) has been mined (Aghzer, 1994; Diot, 1989; El Mahi et al., 2000).

The magmatic and tectonic structures determination and specification of associated mineralized bodies led us to consider geophysical investigations to examine the depths to highlight possible new mineralized deposits, exploitable given the existence of showings that we have collected within this Hercynian context. In this paper, we focus on defining the components and geometry of geological structures and the presence of magma bodies at depth in the massif of Rehamna generally covered by the Mesozoic-Cenozoic sedimentary cover. For this purpose, we proceeded to analyze, and interpretation of the magnetic anomalies of airborne magnetic field data using a geophysical filter (reduction to pole, upward extension, and Euler deconvolution) and a geographic information system validated and confronted by field observations.

\section{Geological Setting}

The Rehamna Hercynian massif is subdivided into two domains (Hoepffner, 1974) separated by a Cretaceous age plateau elongated in the East-West direction (Fig. 1):

- The northern Rehamna corresponds to the Basin of Mechraa Ben Abbou (Imfout and Oued Kibane region);

- The southern Rehamna is represented by the Rehamna massif proper, formed in the north and west by sharp reliefs and a vast, gently undulating plain in the south (Rais-Assa, 1984).

\subsection{Lithostratigraphy}

The Precambrian basement of the Rehamna massif consists of felsic volcaniclastic rocks (Hoepffner, 1974; Hoepffner et al., 2005). It is surmounted by the diversification of silico-clastic and carbonate facies (Figs. 2 and 3), ranging from Lower Cambrian to Visean (Pereira et al., 2015; Hoepffner et al., 2017). Where the Lower Cambrian is represented by dolomitic limestones, calcschists alternating with tuffs and metagraywackes. Overlie by hole shales and phyllades of Middle Cambrian age (Michard, 1982). The upper part of these phyllades corresponds to Paradoxides shales (El Attari, 2001) with volcanic intercalations, then grauwackes with slumpures (Michard, 1982).

Towards the north of the Rehamna massif, these Cambrian series are overlaid by Ordovician series essentially formed of micaceous clay-pelitic deposits, sandstone, and sandstone quartz beds (Cornée, 1982) (Figs. 2 and 3). Silurian-age deposits are thin in the Rehamna massif and are transgressive (El Kamel, 1987; Corsini et al., 1988; Hoepffner et al., 2005). They correspond to limestone platform deposits with incrines (Ben Bouziane, 1995), black schists with graptolites, with intercalation of carbonate and grey-green pelites, intercalated with fossiliferous limestone banks (Hoepffner, 1974; El Kamel, 1987; Corsini et al., 1988). These deposits have mafic lava intercalations that give way upwards to sandstone and quartzitic levels (Cornée et al., 1985; El Kamel et al., 1998; El Attari, 2001) (Figs. 2 and 3). 


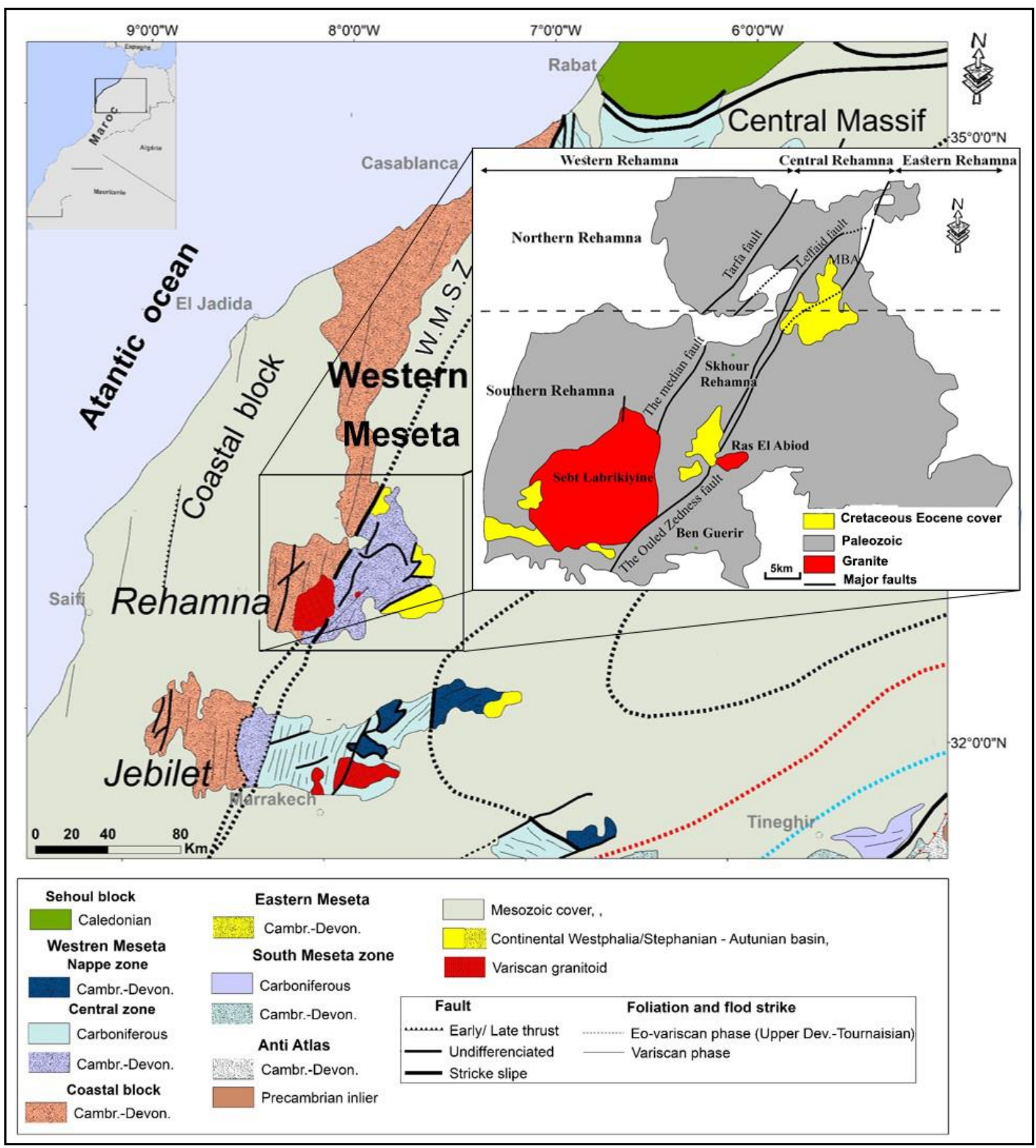

Fig. 1. Simplified geological map of Moroccan Hercynian zones (modified after Hoepffner et al. 2005; Michard et al. 2008; Michard et al. 2010; Chopin et al. 2014). Western Meseta Shear Zone (WMSZ), Mechraa Ben Abbou (MBA)

Silurian-age deposits are thin in the Rehamna massif and are transgressive (El Kamel, 1987; Corsini et al., 1988; Hoepffner et al., 2005). They correspond to limestone platform deposits with incrines (Ben Bouziane, 1995), black schists with graptolites, with intercalation of carbonate and grey-green pelites, intercalated with fossiliferous limestone banks (Hoepffner, 1974; El Kamel, 1987; Corsini et al., 1988). These deposits have mafic lava intercalations that give way upwards to sandstone and quartzitic levels (Cornée et al., 1985; El Kamel et al., 1998; El Attari, 2001) (Figs. 2 and 3). 
Devonian-age deposits are mainly composed of bioclastic bedrock limestone with levels of sandstone and conglomerates that are often red, sometimes plant-based (El Kamel et al., 2000; El Attari, 2001; Hoepffner et al., 2005). The Middle Devonian is formed at Mechraa Ben Abbou from reef limestones. The Upper Devonian shows outcrops of molasses alternating between carbonate sandstone and pelitic sandstone.

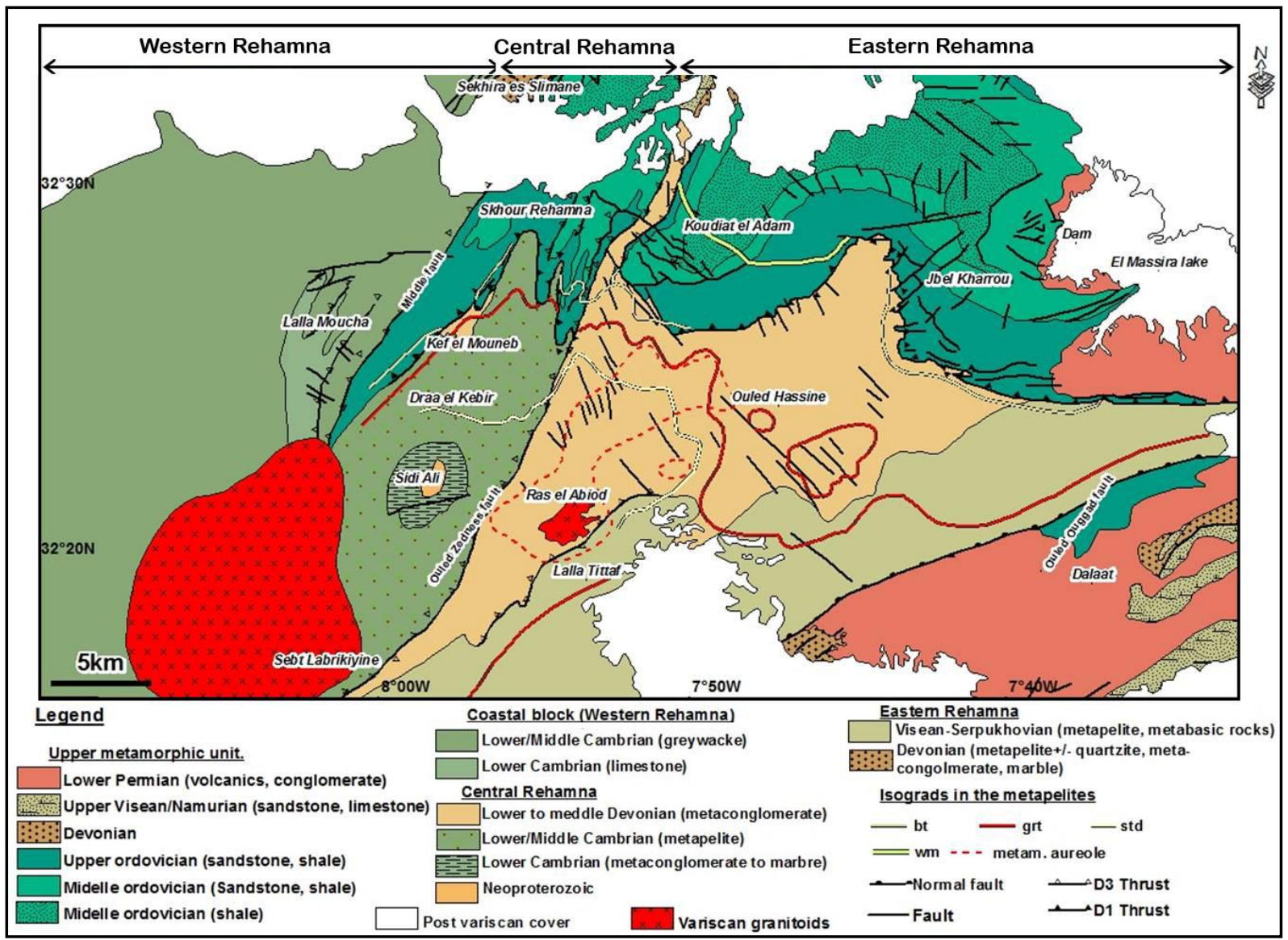

Fig. 2. Structural map of the southern Rehamna (modified from Chopin (2014) with references therein)

The first Late Visean deposits are turbiditic deposits associated with bimodal gabbroic and felsic magmatism (Michard et al., 2010; Delchini et al., 2018). In the northern part of the Rehamna, these deposits correspond to sometimes silicified carbonates, more or less carbonated sandstones, and pyroclastic tuffs with intrusion of dolerites and gabbros (Remmal et al., 1997; Muller et al., 1991; El Kamel and El Hassani, 2006). In the southern Rehamna, the Visean is represented by sandstone, limestone, and amphibolite mica schists (Diot, 1989; Hoepffner et al., 2006, 2005; Wernert et al., 2016). On these Palaeozoic terrains, structured during the Hercynian orogeny, after the Visean, the Permian-aged red continental molasses of Mechraa Ben Abbou from the dismantling of the hercynian belt lie in angular unconformity (El Kamel and Muller, 1987; Saber, 1989; Kholaiq, 2017). The Post-Paleozoic sedimentary cover in the study area is represented by Cretaceous and Mio-Plio-Quaternary deposits to the N-E of the Rehamna massif (Rais-Assa, 1984; Hoepffner et al., 2005). 


\subsection{Tectonic and Tectono-Metamorphism}

The Rehamna massif corresponds to a Hercynian basement, intensely folded and affected by syntectonic metamorphism (Aghzer, 1994; Aghzer and Arenas, 1998; El Mahi et al., 1999). This massif is intersected by two major fault zones trending NNE-SSW. The first corresponds to the West Mesetian Shear Zone, which is represented in the Rehamna by the Median and Tarfa faults (Fig. 1). The second zone corresponds to the Ouled Zedness Fault, the Leffaid Fault, and the Foum El Mejez Fault (Fig. 1), (Aghzer, 1994; Aghzer and Arenas, 1998; Baudin et al., 2003).

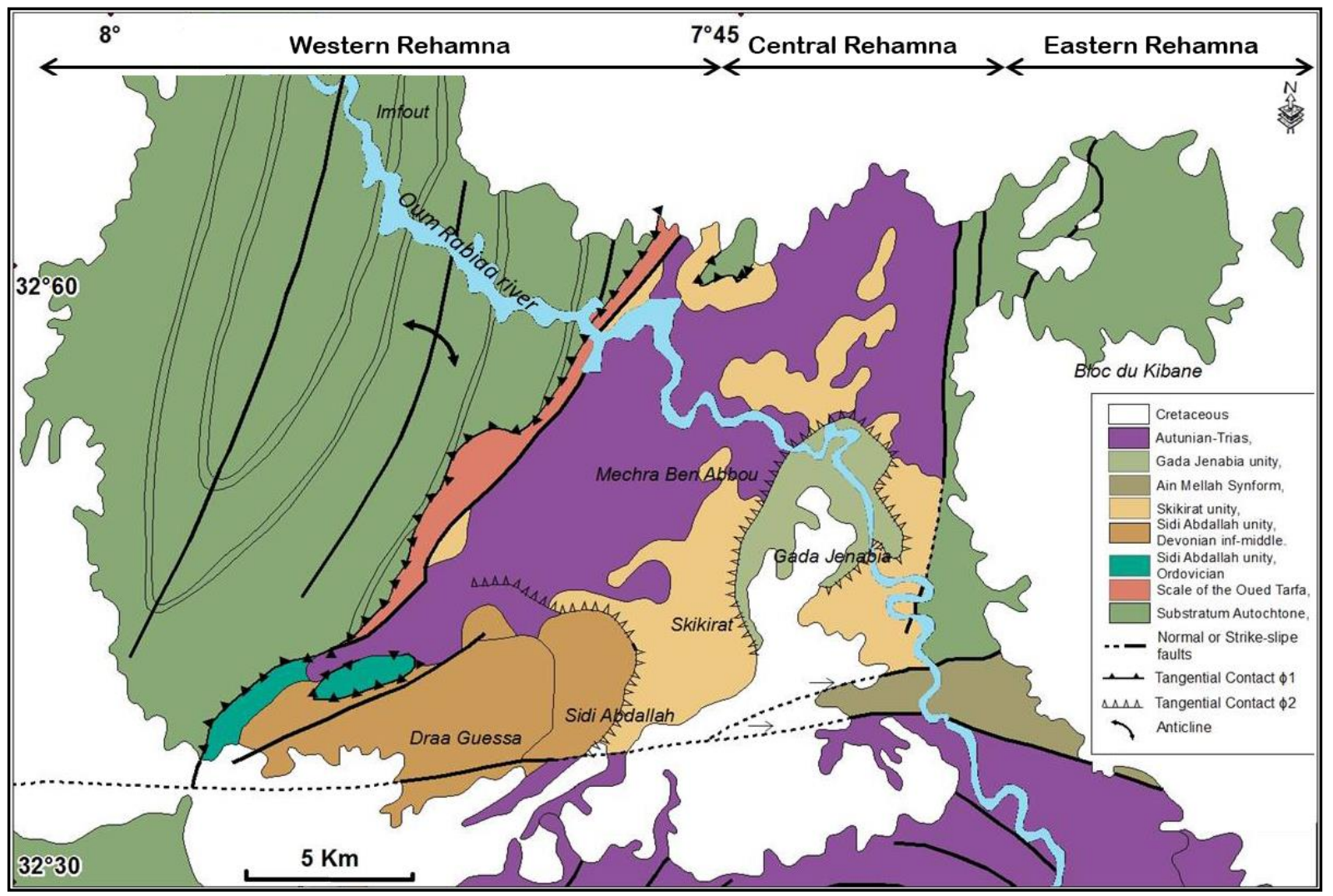

Fig. 3. Structural map of the northern Rehamna Rais-Assa (1984).

The Southern Rehamna are separated into three major structural units (Michard, 1982) Western, Central, and Eastern Rehamna (Fig. 2):

- In western Rehamna, outcrops the Palaeozoic terrains ranging from Cambrian to Devonian, moderately deformed and affected by multi-kilometre scale folding. The metamorphism is anchizonal (Aghzer and Arenas, 1995; El Mahi et al., 2000; Hoepffner et al., 2011; Chopin et al., 2014; Wernert et al., 2016).

- In central Rehamna, the Precambrian to Devonian outcrops (Hoepffner et al., 2011) show a polyphase deformation (Chopin et al., 2014; Wernert et al., 2016) and an epizonal metamorphism, followed by mesozonal to kyanite and staurotide metamorphism (Hoepffner et al., 1975; Corsini et al., 1988; El Mahi, 1991; Hoepffner et al., 2011; Chopin et al., 2014; Hoepffner et al., 2017).

- In Eastern Rehamna, the Cambrian to Upper Visean terrains (Hoepffner et al., 1975; Aghzer and Arenas, 1995) also exposed polyphase deformation (Chopin et al., 2014; Wernert et al., 2016). The folds are concentric, flattened, and oriented N45, recumbent with an NW-verging, slightly affected by NNE-SSW landslides and shears (Hoepffner et al., 1982; Aghzer, 1994; Saidi et al., 2002; 
Baudin et al., 2003; Kholaiq, 2017). The metamorphism accompanying the shear deformation is mesozonal, characterized by a garnet, staurotide, and chloritoid paragenesis (El Mahi et al., 1999).

\subsection{Magmatism}

The Rehamna are characterized by the emplacement of numerous granite and granodiorite plutons (Fig. 3) of Visean-Autunian age (330-290 Ma) (Michard et al., 2010), contemporary to the sedimentation of the Upper Visean (Michard et al., 2010). These felsic magmatic rocks occur in the field as diapirs (Baudin et al., 2003; Tahiri et al., 2007; Michard et al., 2010), or laccolites (Boummane and Olivier, 2007; Michard et al., 2010). They are the result of a mixture of mafic magmas from the mantle more or less enriched in major chemical elements $\left(\mathrm{MgO} ; \mathrm{Al}_{2} \mathrm{O}_{3} ; \mathrm{CaO} ; \mathrm{Na}_{2} \mathrm{O}\right.$ and $\left.\mathrm{K}_{2} \mathrm{O}\right)$ and anatectic magmas, derived from the partial fusion of the continental crust (Gasquet et al., 1996; Haïmeur and Hassani, 2005; El Hadi et al., 2006; Michard et al., 2010). In the Carboniferous basins of the Rehamna massif, felsic intrusions are generally posterior to mafic magmatism. Although some magmatic breccias locally suggest concomitant Upper Visean emplacement (Essaifi et al., 2003; Michard et al., 2010).

The prerequisite magmatic rocks of the Rehamna in the north are mainly intrusive in the Lower Devonian to Upper Devonian series (Fig. 3), where they form stratiform bodies; Layered veins, sills, and laccolites (Remmal et al., 1997; El Kamel and El Hassani, 2006). These rocks are subdivided into two groups (El Kamel and Muller, 1987; El Mahi, 1991; Kharbouch, 1994; El Kamel, 2002):

- A pre-orogenic set corresponds to sills of dolerites and gabbros in the Visian series, whereas in the Lower Devonian presents a structure of dykes (Gigout, 1951; El Kamel, 1987).

- A post-orogenic ensemble formed by volcanic flows is associated with post-orogenic molasses and micro-dioritic veins (El Kamel, 1987; Kharbouch, 1994).

In the southern Rehamna, in addition to these two large magmatic assemblages, there are synchronous to post-kinematic granitic plutons (Kharbouch, 1994), represented in the axis of the median fault by the Sebt Labrikiyine granite and in the eastern Rehamna by small granitic eruptions (Ras El Abiod or Ouled Zbir, Koudiat Ermel and Raïchet) (Diot, 1989; El Mahi et al., 2000; Michard et al., 2010). We also note the existence of microgranite sills, arranged parallel to the Ouled Zedness accident as well as factoid veins, oriented N70 to N80 in the vicinity of this accident (Aghzer, 1994; Diot, 1989).

\section{Geophysical Data and Processing}

The choice of the magnetic method has been justified by the high variability of the magnetic susceptibility in the Rehamna massif. That is favorable to good magnetic discrimination within this domain. Moreover, the broad coverage of airborne magnetic data in Rehamna massif allows good visibility of underground structures and their correlation with outcrops, using the analysis of maps in isogrammatic curves of the residual magnetic field data at 1/100.000. The maps used in this study are the product of an airborne survey of magnetic (C.A.G., 1970), which entrusted by the Ministry of Energy and Mines of Morocco, covered by a fifty-three-lines flight path. The airborne equipment includes a cesium vapor CSF $\mathrm{n}^{\circ} 21$ type magnetometer with a diffusion beam with six intermeshing beams. The flight lines spacing was $3 \mathrm{~km}$, and the orientation was SE $120^{\circ}$. There are twenty tie lines with a spacing of $8 \mathrm{~km}$ and $\mathrm{NE} 30^{\circ}$ orientation. The barometric flight height was $1000 \mathrm{~m}$. Besides that, in order to process digital airborne magnetic field data, we used Oasis montaj 7.0.1 and Arcgis 10.1 software (Fig. 4). The magnetic data analysis allowed us to highlight the different magnetic components of the bodies susceptible to be mineralized and their spatial positioning. Also allowed us to update the structural data on the geological maps within the study area.The residual magnetic field was reduced to a pole using the Fourier transform $\left(\right.$ Inclination $=47^{\circ}$ and Declination $=-7.4^{\circ}$ ). This reduction to pole (RTP) map is the basis of the application of various mathematical filters below; Namely qualitative (upward continuation) 
and quantitative (Euler deconvolution) interpretation, to correlate and create a complement to the outcrop map.

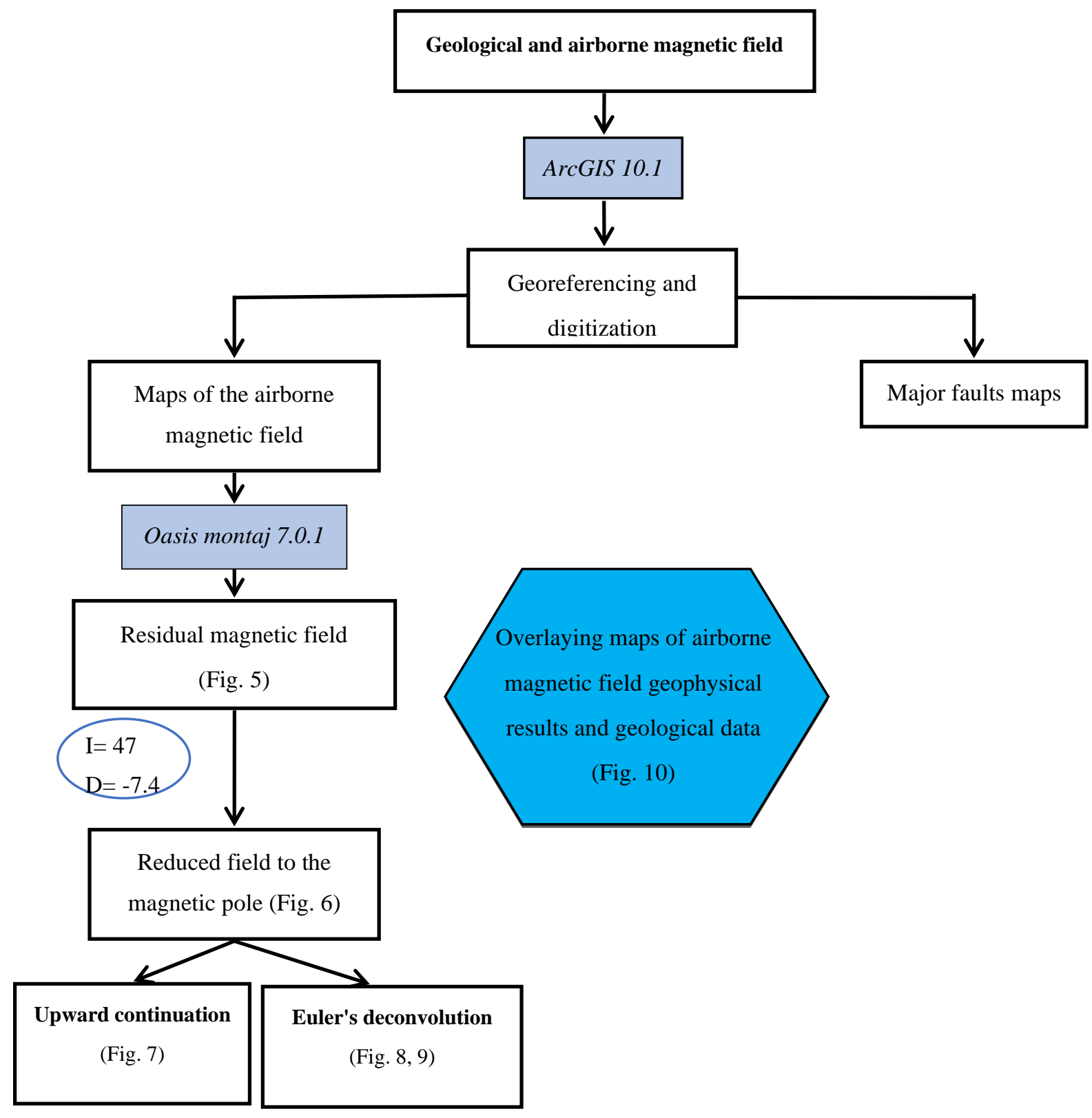

Fig. 4. Methodology of magnetic analysis data

\subsection{The Residual Magnetic Field and Reduction to Pole}

For better visualization of these magnetic anomalies and to facilitate the analysis and structural interpretation of the results, the residual airborne magnetic field (Fig. 5) was reduced to pole (RTP) to eliminate the distortion of the anomalies caused by the inclination of the Earth's magnetic field (Debeglia, 2005; El Gout et al., 2009). This filter brings the magnetic anomaly back to its geological source in the Rehamna massif, using the Fourier transform (Fourier, 1822) (Inclination=47, Declination=-7.4). The Fourier transform reduction to pole formula 1 is given by the following relationship (Blakely, 1995): 


$$
R p=\frac{1}{\left(\sin \left(I_{Y}\right)-i \cos (I \alpha) \cos (D+\theta)\right)^{2}}
$$

With:

$i$ : The geometric inclination;

$I_{Y}$ : Inclination for correction of the real component $\left(I_{Y}>\mathbf{1}\right)$;

$I \alpha$ : The geomagnetic inclination;

$D$ : The geomagnetic declination;

$\boldsymbol{\theta}:$ The phase.

The RTP map of this filter (Fig. 6) is used as a base for all the filters used thereafter. This filter allows to obtain anomalies whose maximum is centered on the magnetic sources.

\subsection{Upward Continuation}

To separate the anomalies due to magnetic sources at the surface from those at the deep, we carried out a theoretical calculation by applying the "Upward Continuation Filter (UP)" (Ivan, 1986) (Fig. 7). This filter allows a qualitative analysis of the distribution. That is shown to be of the magnetic anomaly sources, mainly at different depth levels. Moreover, it tends to allow the attenuation of short wavelengths (Mekonnen, 2004). The reduced magnetic anomaly map to the pole is extended upwards so that the signal of small superficial magnetic bodies at short wavelengths disappears. It also allows us to highlight the anomalies of deep sources at long wavelengths. The expression 2 of the upward continuation operation is as follows (Sailhac, 1999), based on Green's identities:

$$
U(x, y, Z 0-\Delta Z)=\frac{\Delta Z}{2 \pi} \iint \frac{U\left(x^{\prime} y^{\prime}, 0\right)}{\left.((x-x))^{2}+\left(y-y^{\prime}\right)^{2}+\Delta z^{2}\right)^{\frac{3}{2}}} d x^{\prime} d y^{\prime}
$$

\section{With $\Delta \boldsymbol{Z}>0$}

Where $Z 0$ is the aircraft's elevation and $\Delta Z$ the reference plane.

\subsection{Euler's Deconvolution}

Euler deconvolution is a filtering method applied to magnetic data, based on a mathematical combination (3) (Beasley and Golden, 1993; Fairhead et al., 1994; Mushayandebvu et al., 2001; Silva and Barbosa, 2003). This method requires the possibility to delineate contacts in the horizontal plane with the evaluation and estimation of their directions and depths. It depends on the appropriate choice of the structural index (SI=0, 1, 2, or 3) (Amigun et al., 2012), which is a function of the magnetic body's geometry. The support of our study is the map of the magnetic field reduced to pole based on the following relationship (Reid et al., 1990):

$$
\frac{\left(x-x_{0}\right) \delta T}{\delta x}+\frac{\left(y-y_{0}\right) \delta T}{\delta y}+\frac{\left(z-z_{0}\right) \delta T}{\delta z}=N(B-T)
$$

With

$x_{0} ; y_{0} ; z_{0}$ : Coordinates of anomaly source; 
$N$ : Structural Index;

$B$ : Value of the regional field;

$T$ : Value of the total field $(x, y, z)$.

The calculation of the three derivatives according to $\mathrm{x}, \mathrm{y}$ and $\mathrm{z}$ are necessary to carry out the filter of the Euler deconvolution, knowing that the barometric altitude is $1000 \mathrm{~m}$.

Derivative according to $\mathrm{x}$

$$
O D x=i \gamma K x
$$

Derivative according to $\mathrm{y}$

$$
O D y=i \beta K y
$$

Derivative according to $\mathrm{z}$

$$
O D z=i \gamma|K|
$$

The choice of the structural indexes mentioned above is imposed by the geological context of our study area. To locate magnetic contacts with a high, throw we selected Structural Index SI=0 (Fig. 8), and for interactions with the low throw, the Structural Index SI=1 (Fig. 9) relative to sills and dykes.

\section{Results and Discussion}

\subsection{Residual Magnetic Field Map}

The residual magnetic field map of the Rehamna massif (Fig. 5) shows several anomalies of variable shape, size, and intensity. Thus, in this studied area, we have N-S to NNE-SSW and NE-SW extensions with residual magnetic field intensities ranging from -74 to $93 \mathrm{nT}$. The sectoral analysis of the fields of interest in the Rehamna shows ten areas (Fig. 5):

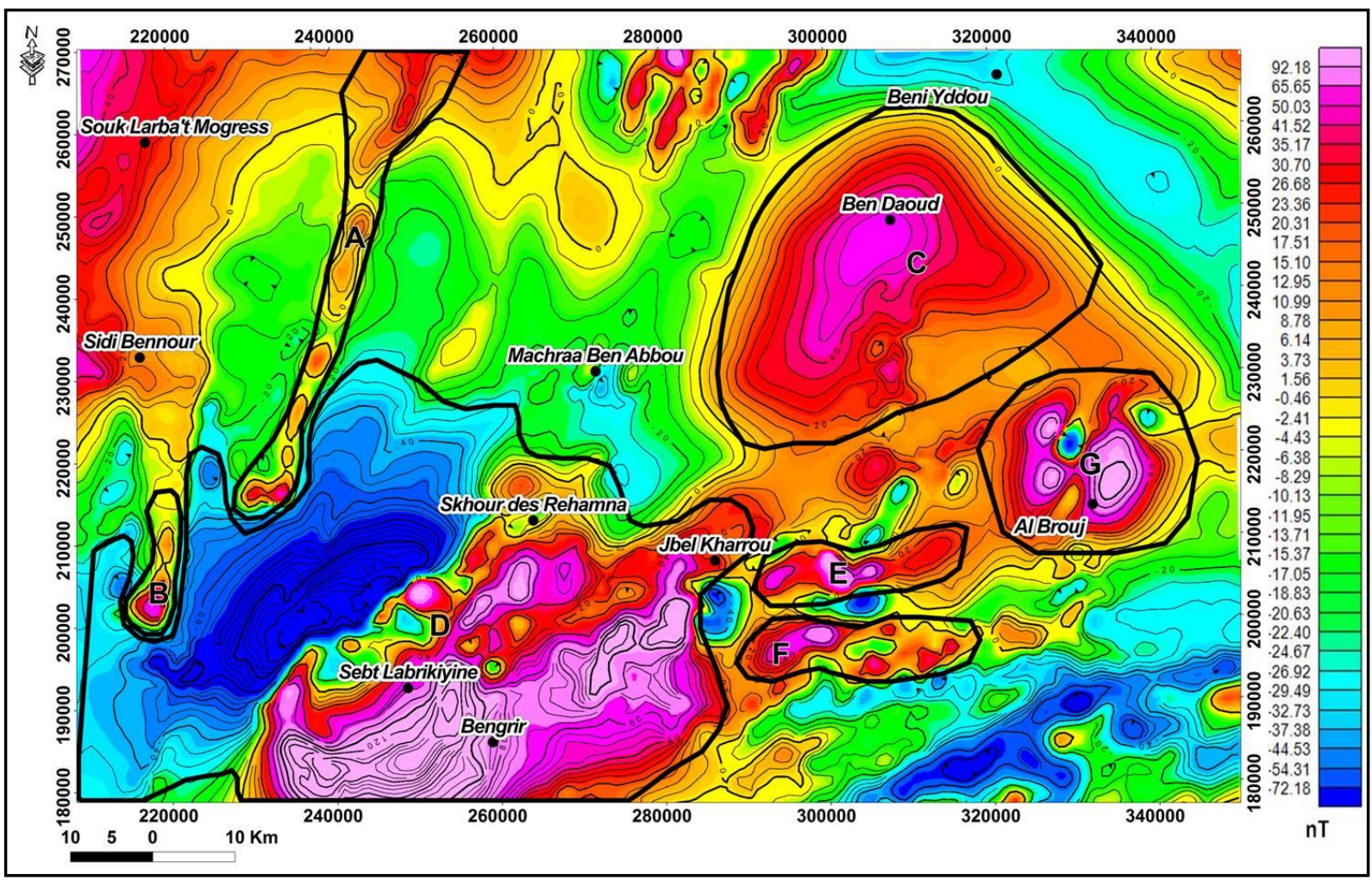

Fig. 5. Residual magnetic field map 
- Area A: has a set of positive anomalies aligned along an NNE axis; the longest wavelength in this set is represented by an intensity anomaly of $26.3 \mathrm{nT}$. It is an area hidden by the quaternary (old alluvium).

- Area B: shows a positive magnetic axis-oriented N-S, with two "sub-areas" of different intensity (44.4 $\mathrm{nT}$ and $-0.6 \mathrm{nT})$.

- Area C (Ben Douad): This shows two positive anomalies. One anomaly is $35.53 \mathrm{~km}$ long and 14.02 $\mathrm{km}$ wide, trending NNE-SSW with an intensity of $39.7 \mathrm{nT}$. The second one is relatively small, 3.93 $\mathrm{km}$ long and $2.91 \mathrm{~km}$ wide, oriented N-S with an intensity of $51.5 \mathrm{nT}$. This anomaly is hidden by sedimentary rocks of the secondary cover (Limestone, Marls and marly phosphates).

- Area D: located in the south-western part of our study area. It displays a large dipolar ordinary anomaly-oriented NE-SW. By a positive pole to the south, the anomaly is formed and characterized by an intensity of $188.4 \mathrm{nT}$, with a length of $56.39 \mathrm{~km}$, and a negative pole to the north shows NE-SW trending anomaly with an intensity of $-141.2 \mathrm{nT}, 45.57 \mathrm{~km}$ long, and $16.46 \mathrm{~km}$ wide. The abnormality shows four highly visible magnetic axes; one axis is oriented NE-SW, and the other three are oriented N-S. This anomaly looks like the dipolar anomaly of the Hajar jebilet mine (Jarni et al., 2015). This anomaly describes two types of geological formations: mainly magmatic rocks rich in ferromagnesium and sulfide mineralization with pyrite and chalcopyrite, generally aligned.

- Area E: a set of positive magnetic anomalies-oriented E-W, composed of three anomalies of intensities $15.6 \mathrm{nT}, 56.93 \mathrm{nT}$, and $95.98 \mathrm{nT}$.

- Area F: shows a set of positive anomalies with a remarkable decrease in intensity from west to east.

- Area G: shows one positive and two negative oriented N-S anomalies, more or less circular in shape. On the first hand, the largest positive anomaly has a dimension of $12.70 \times 7.84 \mathrm{~km}$ with an intensity of $114.4 \mathrm{nT}$. In the other hand, the other two anomalies have an intensity of $83.7 \mathrm{nT}$ and $83.1 \mathrm{nT}$. The magnetic source of this anomaly is always hidden by sedimentary rocks (limestone and marl) that form the secondary cover.

\subsection{Reduced Magnetic Field to Pole Map (RTP)}

- Analysis of the RTP map reveals ten areas of interest as a function of the intensity factor, size, and nature of the magnetic source (Fig. 6):

- Areas A and B: Areas A show an alignment of positive, oriented NNE-SSW. Area B show a positive oriented N-S anomaly with an intensity of $41.52 \mathrm{nT}$ hidden by a plio-quaternary cover. These two areas meet where Tertiary and Quaternary terrains outcrop (clay, sandstone, limestone and alluvium).

- Area C: shows a positive NNE-SSW trending anomaly with an intensity of $70.2 \mathrm{nT}$, which is associated with secondary age soils (limestone, marl and marl-phosphates). The high magnetic intensity in this area could be related to magmatic rocks (basaltic lavas, dolerites, and gabbros) described by many authors (Gigout, 1951; El Kamel, 1987; Kharbouch, 1994) that are trapped at a few meters' depth.

- Area D: shows an increase in magnetic field strength after applying the reduction to pole which reaches $212.92 \mathrm{nT}$. This area is elongated in the NNE-SSW direction, then reorienting N-S to the north, and relocated the anomaly in line with the magnetized mineralized structures. From the lithological point of view, the southern part of this area overlaps perfectly with the Hercynian granite areas (Rehamna granite) and metamorphic rocks (Hornfels, Gneisses and Phyllades).

- Area E: reveals two positive anomalies, which are changed in shape and orientation after the reduction at the pole; the first is oriented NE-SW with a strength of $41.16 \mathrm{nT}$ and the second is oriented NNW-SSE with a strength of $126.33 \mathrm{nT}$. This area shows outcrops of eruptive rocks 
(rhyolite and dacite) of Carboniferous age and red clays, sandstones and conglomerates of Permian and Triassic age.

- Area F: presents a positive anomaly-oriented E-W with an intensity of $32.38 \mathrm{nT}$. It is located where facies of regional metamorphic rocks (gneiss) related to the Hercynian orogeny and eruptive rocks (rhyolite and dacite) outcrop (Razin et al., 2003).

- Area G: shows two elongated positive anomalies along the N-S direction, with two different intensities, $121.6 \mathrm{nT}$ and $93.5 \mathrm{nT}$, which are separated by two negative anomalies. These two positive anomalies are located in concordance with carbonate terrains of Eocene age, which are detached by an anomalous contact. This anomaly could be caused by the magnetic response of magmatic rocks trapped at depth.

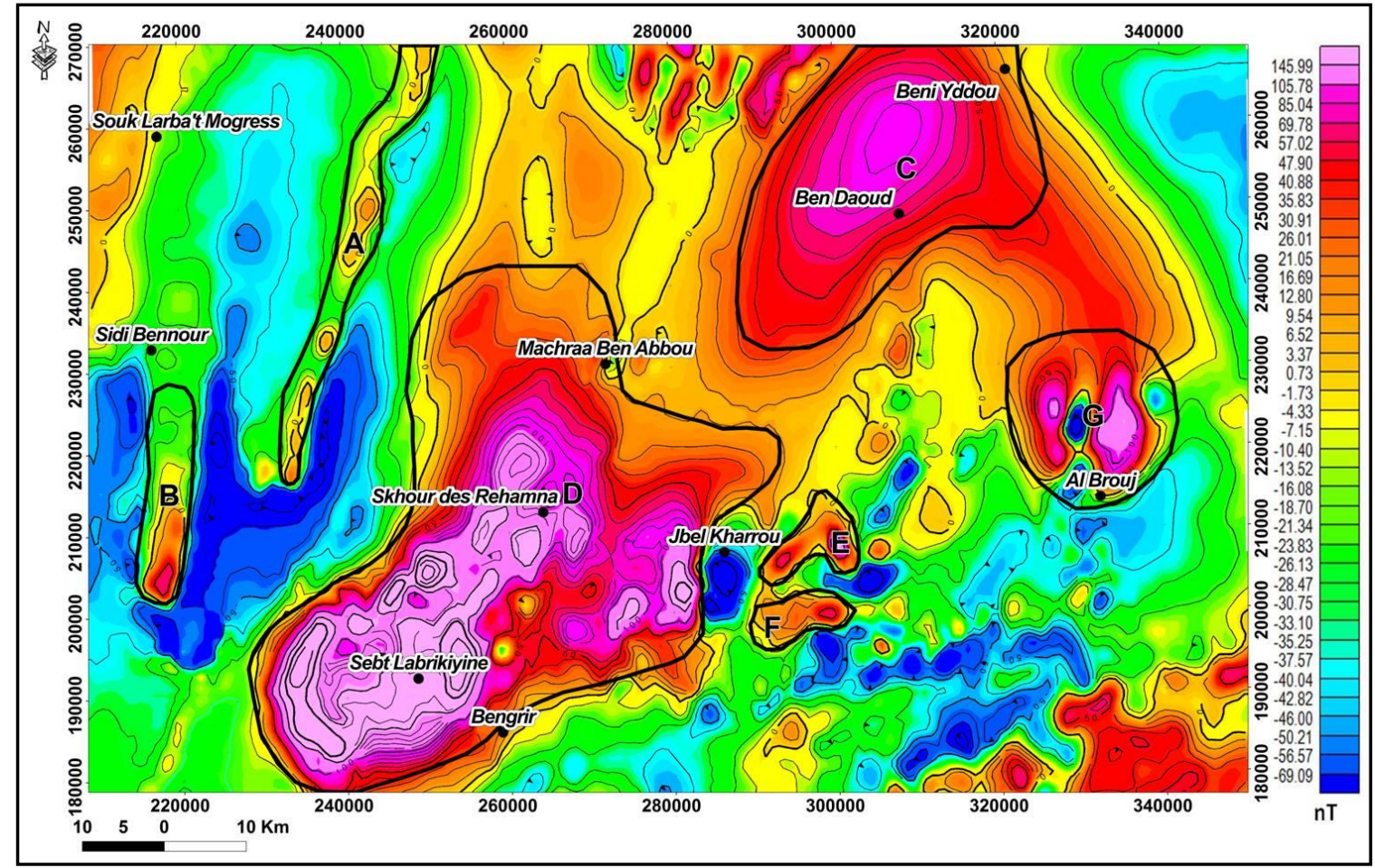

Fig.6. Map of the reduction of the pole

South of Jbel Kharrou, a negative N-S trending anomaly presents an intensity of -186.43 nT. It is due to the effect of weakly magnetized rocks (sandstone, quartzite, and schists) of the Silurian age and Quaternary alluvium. The passage of the major normal fault in the middle of the anomaly and the emplacement of the Hercynian eruptive rocks (rhyolite and dacite) present an observable increase in magnetic intensity. The RTP map allowed determining several anomalies of positive and negative magnetic intensity. It also helps to map two main positive magnetic anomalies. The direction is NE-SW; The first one around Skhour Rehamna fits perfectly with the magmatic rocks (granite, gneiss, gabbro, dacite...), indicating its continuity in the hidden zones. The second one is the most extensive of the zone covering Cretaceous age terrains. Most rocks in the outcrop have a magnetic quality that encourages one to think of a deeper origin and indicates that its source is deeply underground.

\subsection{Magnetic Field Reduced to Pole Extended Upwards Maps}

The obtained result from the calculation at an altitude of two kilometers (Fig. 7) generates a map with great similarity with the map reduced to pole, with a difference in intensity that varies between $113 \mathrm{nT}$ and $-48 \mathrm{nT}$. 
The analysis of the RTP map extended upwards, shows that the higher the altitude of the extension, the more the amplitude of the anomalies decreases or disappears. However, there are restrictions regarding the partial or total disappearance of the anomaly during the change in altitude. Indeed, we sometimes have areas includes static anomalies at and around the Sebt Lbrikiyine granite, Lalla Tittaf, and Ras Abioud, and in the Ben Daoud area.

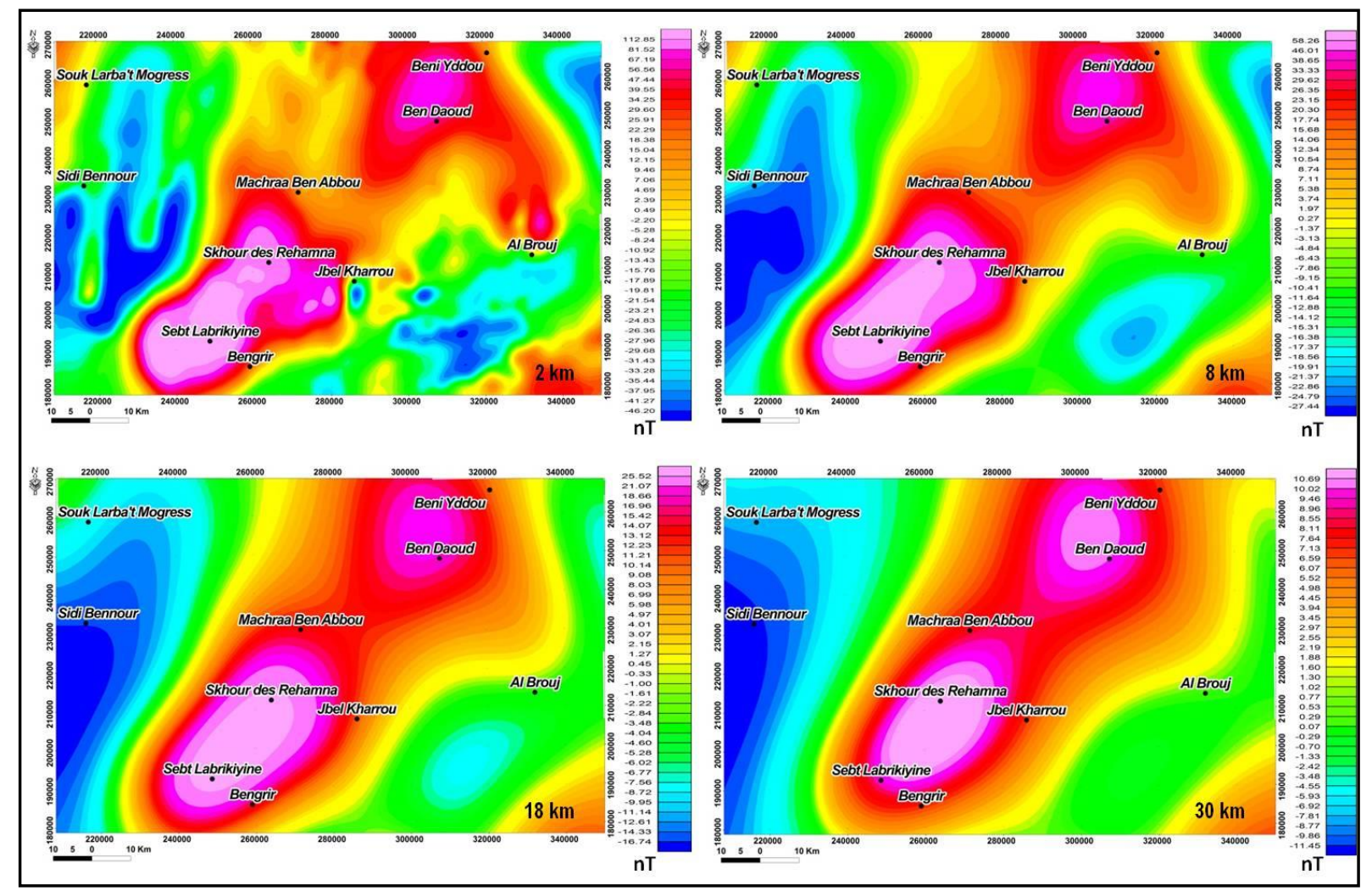

Fig. 7. Reduced maps to the pole extended upwards to 2, 8, 18 and $30 \mathrm{~km}$

Moving up from elevation two kilometers to elevation thirty kilometers, the southeast area of the map shows anomalies that interfere and merge into a single anomaly. Other anomalies diminish in shape and extension, as in the case of the Ben Daoud anomaly, and in some cases, they disappear completely, as in the case of the area north and south of El Brouj. The Ben Daoud anomaly has a very high depth according to its appearance corresponds to a deep pre- and post-orogenic magmatic rock structure with a very high magnetization under the secondary and tertiary cover. So, we have here the spatial evolution of this structure. On the other hand, the Sebt Labrikiyine-Skhour Rehamna anomaly keeps the same shape with the same extensions and corresponds to a basement structure with a ferromagnesian granitic component of Sebt Labrikiyine. The negative magnetic axis to the south of Souk Larba't Mogress moves with the extension upwards and indicates the eastward's direction dip of this contact.

\subsection{Euler deconvolution}

The solutions of the Euler deconvolution for the structural index SI=0, the tolerance T=15\%, and the size of the window is $\mathrm{W}=8 \mathrm{~km} \times 8 \mathrm{~km}$ (Figs. 8 and 10) are located at depths between 0.03 and $-7327.38 \mathrm{~m}$. The greatest depths are recorded in the northeastern part of the study area. In this part, the number of the deepest solutions is very high compared to the other solutions. 


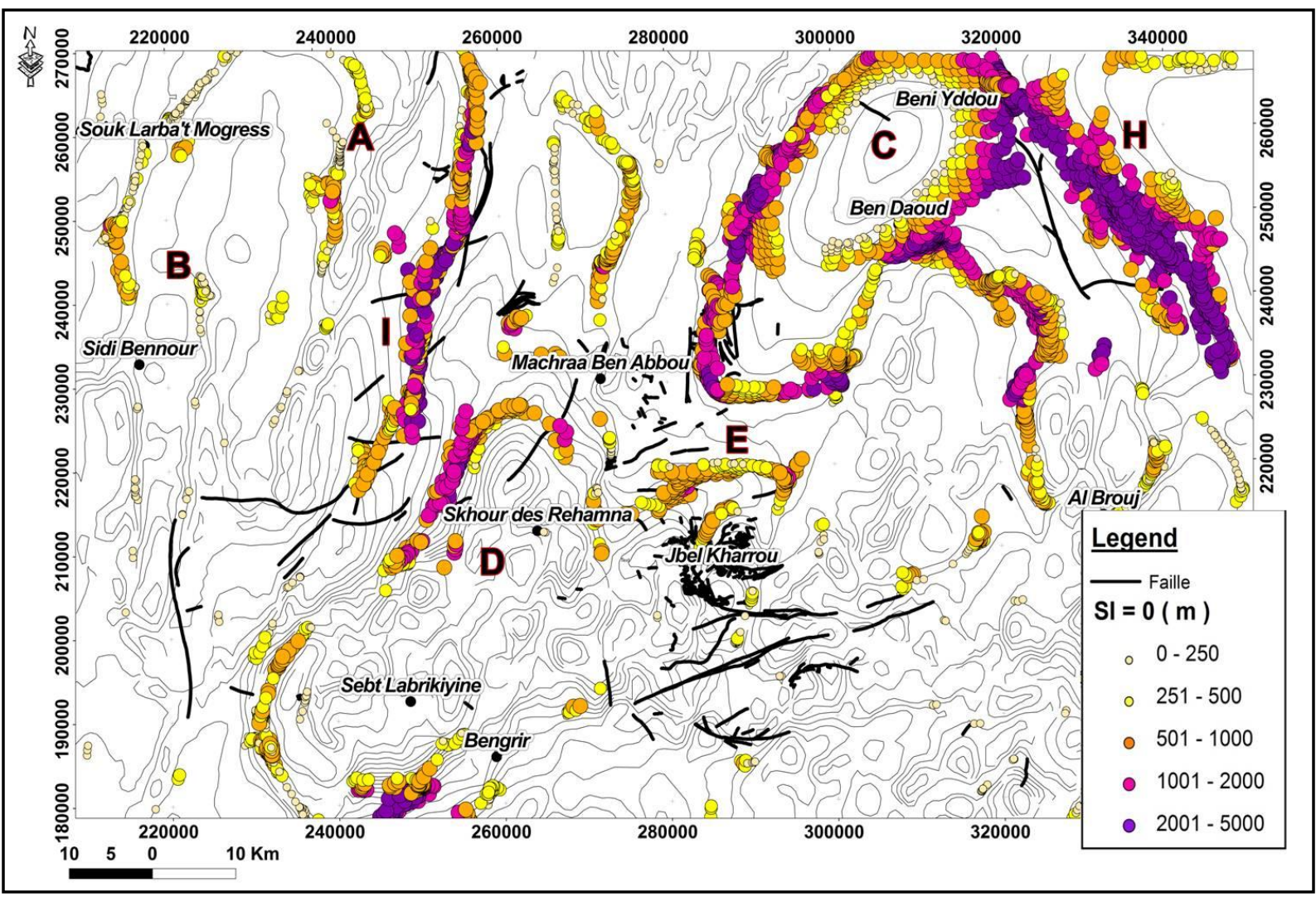

Fig. 8. Superposition of Euler solutions $(\mathrm{SI}=0)$ and geological accidents of the Rehamna massif on the Map of reduction to pole

Thus, to interpret the solutions obtained by the Euler deconvolution calculation, these results were superimposed on the structural map of our study area. The analysis of the Euler result $(\mathrm{SI}=0)$ according to the areas of importance allowed us to distinguish seven areas:

- Area A: in this area, Euler solutions are aligned in N-S direction and correspond to contact up to $2700 \mathrm{~m}$ deep, and it is recovered by the Pliocene and Quaternary deposits of the Coastal Meseta.

- Area B: corresponds to the kilometric scale fault that outcrops north of Sidi Bennour and oriented N-S (Choubert 1946-1953). Euler's solutions have revealed an alignment that could be the extension and rooting of the fault mapped by Choubert 1946-1953 to the north at a depth of about two thousand meters. To the West and parallel to this fault appears another contact with high throw elongated north of Sidi Bennour a few kilometers to Souk Larba't Mogress.

- Area C: to the North-East of Mechraa Ben Abbou, between Beni Yaddou and Ben Daoud, Euler's solutions form a special structure-oriented NNE-SSW. This structure reaches depths of approximately $5094 \mathrm{~m}$. This structure is the expression of a magmatic body, maybe gabbroic (Kholaiq, 2017).

- Area D: the zone between Sebt Labrikiyin and Skhour Rehamna is underlined by NNE-SSW trending contact. The deepening of the Euler deconvolution's solution towards the southwest varies from $0.03 \mathrm{~m}$ to $-1628 \mathrm{~m}$. Towards the North-East, the solutions reach the value of $4141 \mathrm{~m}$ of depth.

- Area E: North of Jbel Kharrou, Euler's solutions follow the E-W direction of the large contacts mapped on the geological maps (Baudin et al., 2003; Razin et al., 2003) of the area. In the vicinity of this area, the fault directions change to the E-W trending. Depths obtained vary from $278 \mathrm{~m}$ to $3700 \mathrm{~m}$. 
- Area H: the interpretation of this area has revealed a very deep contact about the different areas of the map with the appearance of a double point approximately at $7330 \mathrm{~m}$ depth. The direction of this structure is different in comparison with the other contacts (NNW-SSE). Euler's solutions in this area combine between the two faults mapped on the geological map (Salvan, 1985) and give the shape of an orogenic basin (basin on offset type). Calculation of the Euler deconvolution for the structural index $\mathrm{SI}=1$, the tolerance $\mathrm{T}=15 \%$, and the size of the window $\mathrm{W}=8 \mathrm{~km} \times 8 \mathrm{~km}$ (Fig. 9) show contacts of low discharges, which are located at calculated depths up to about twelve thousand meters.

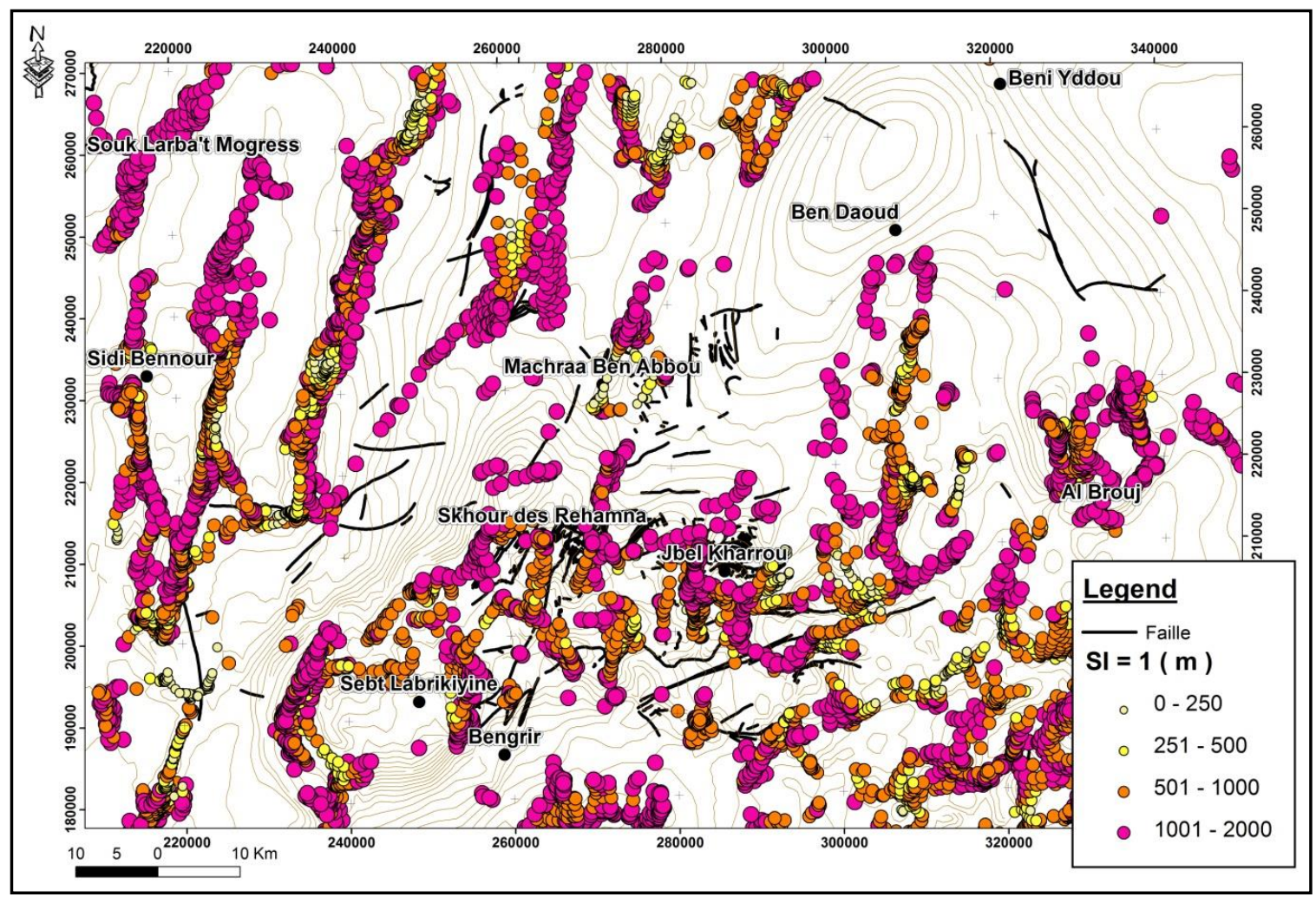

Fig. 9. Superposition of Euler solutions $(\mathrm{SI}=1)$ and geological accidents of the Rehamna massif on the Map of reduction to pole

- Area I: to the West of Mechraa Ben Abbou, this area is characterized by faults mapped in different directions (E-W, N-S, and NNE-SSW), and is intersected by Euler's result which rises from 4 kilometers to the surface. The contacts obtained from Euler affect Mesozoic formations cover and Cambrian formations composed by Schists, Sandstones, and Imfout Quartzites. Euler's solutions calculated with SI=1 (Figs. 9 and 10) further emphasize the already known NNE-SSW and N-S trending contacts (Baudin et al., 2003; Razin et al., 2003). The largest contacts presented by the Euler solutions are located south of Sidi Bennour. The corresponding depth varies from 0.03 to $-1967.88 \mathrm{~m}$. Between Mechraa Ben Abbou and Sidi Bennour, we have a depth ranging from 0.03 to $-3182.38 \mathrm{~m}$. To the South-West of this area, we highlighted several contacts-oriented N-S, NE-SW, NNE-SSW, and NW-SE.

\section{Conclusions}

The analysis and interpretation of airborne magnetic field data relating to the Rehamna area have enabled us to better define the components and geometry of geological structures of the Variscan granitoid of Rehamna. Our field investigations revealed the existence of sulphide occurrences related to 
some of the components and structures in the study area. This airborne magnetic field study also provided results that offer a more precise understanding of the massif. Thus, the qualitative and quantitative numerical processing of these data by upward extensions and Euler deconvolution enabled the detection of several magnetic anomalies at the surface and/or at depth. Our processing also revealed the main geological structures in the massif of Rehamna.

According to the result obtained from the first filter reduction to pole, there is a great heterogeneity of the subsurface in terms of magnetic magnetization. We also noticed the existence of anomalies of strong amplitudes, which are concentrated in particular near Skhour Rehamna / Sebt Labrikiyine, Ben Daoud, and El Brouj. This anomaly explains the existence of magnetic facies represented by basic and acidic rocks rich in ferromagnesium. These anomalies are significantly elongated and generally extend in a NE-SW direction. The upward extension shows a clear boundary between the highly magnetized formation, which has the basement, and the less magnetized formation, which is very deep. They obviously correspond to the Hercynian Ferromagnesian granitic outcrops in the southern part of the Rehamna massif. On its western side, the massif is bounded by a deep contact-oriented NNE-SSW, and in the northeastern part, our study area is bounded by another very deep contact-oriented NNW. Finally, the Euler deconvolution's solution is obtained by using the various structural index, clearly underline this limit as well as other lineaments down to depths of about twelve thousand meters. The directions revealed are NNW-SSE, N-S, NNE-SSW, NE-SW, and E-W. These results allowed us to update the geological mapping data of the Rehamna massif, and their overlay analysis led us to locate the structures that may be of interest for mineralization trapping at the fault areas around granitic outcrops.

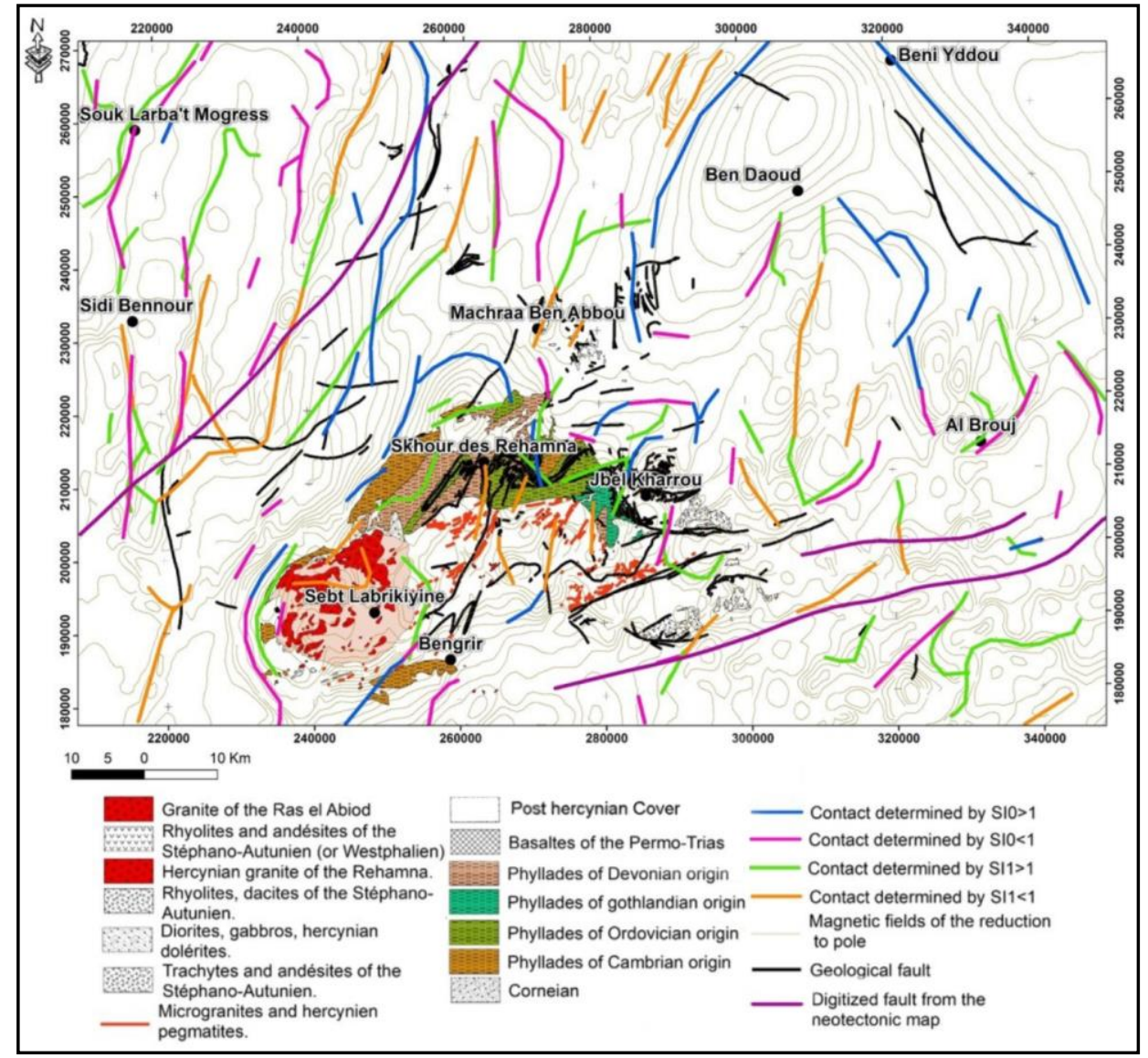

Fig. 10. Comparison between the Euler Deconvolution ( $\mathrm{SI}=0$ and $\mathrm{SI}=1$ ) and the geological accidents 


\section{Acknowledgments}

The authors are very grateful to the reviewers, Editor in Chief Prof. Dr. Salih M. Awadh, the Secretary of Journal Mr. Samir R. Hijab, and the Technical Editors for their great efforts and valuable comments.

\section{References}

Aghzer, A.M., 1994. Evolution tectonothermale du massif hercynien des Rehamna (Zone centre-mesetienne, Maroc). These doctorale. Universidad complutense de madrid. Facultad de ciencias eológicas. Complutense, Madrid.

Aghzer, A.M., Arenas, R., 1998. Evolution métamorphique des métapélites du massif hercynien des Rehamna (Maroc): implications tectonothermales. Journal of African Earth Sciences, 27(1), 20.

Aghzer, A.M., Arenas, R., 1995. Détachements et tectonique extensive dans le massif hercynien des Rehamna (Maroc). Journal of African Earth Sciences, pp. 383-393. https://doi.org/10.1016/0899-5362(95)00096-C.

Amigun, J.O., Afolabi, O., Ako, B.D., 2012. Euler 3-D Deconvolution of Analytical Signal of Magnetic Anomalies over Iron Ore deposit in Okene, Nigeria. Journal of Emerging Trends in Engineering and Applied Sciences 3, 711-717.

Baudin, T., Chevremont, P., Razin, P., Youbi, N., Andries, D., Hoepffner, C., Thieblemont, D., Chihani, E.-M., Tegyey, M., 2003. Carte géologique du Maroc au 1/50 000 Feuille de Skhour des Rehamna. Ministère de l'Energie et Mines. direction de la Géologie. Edition du service géologique du Maroc. Notes et Mémoires $\mathrm{N}^{\circ} 435$.

Beasley, C.W., Golden, H.C., 1993. Application of euler deconvolution to magnetics data from the Ashanti Belt, Southern Ghana, in: SEG Technical Program Expanded Abstracts 1993. Presented at the SEG Technical Program Expanded Abstracts 1993, Society of Exploration Geophysicists, 417-420.

Ben Bouziane, A., 1995. Evolutions sédimentologique et diagenétique des carbonates du Dévonien de la Meseta marocaine occidentale (Oulad Abbou, Mechraa Ben Abbou et Doukkala). These de Doctorat. Université Hassan II, Mohammedia. Faculté des sciences Ben M'sik. Casablanca.

Benyas, K., Aarab, A., Qarbous, A., Lakhloufi, A., Manar, A., Amar, M., Idrissi, A., Elmimouni, M., 2021. Exploiting Aeromagnetic and Gravity Data Interpretation to Delineate Massif Deposits of Rehamna Area (Western Meseta-Morocco). Iraqi Geological Journal 54, 13-28.

Blakely, R.J., 1995. Potential theory in gravity and magnetic applications., La presse de l' Universite de Cambridge.

Bordonaro, M., Gaillet, J.-L., Michard, A., 1979. Le géosynclinal carbonifère sud-mésétien dans les Jebilet (Maroc); une corrélation avec la province pyriteuse du Sud de l'Espagne.

Boummane, M.H., Olivier, Ph., 2007. The Oulad Ouaslam Variscan granitic pluton (Jebilets Massif, Southwestern Moroccan Meseta): A forcibly emplaced laccolithic intrusion characterized by its magnetic and magmatic fabrics. Journal of African Earth Sciences 47, 49-61.

Chopin, F., Corsini, M., Schulmann, K., El Houicha, M., Ghienne, J.-F., Edel, J.-B., 2014. Tectonic evolution of the Rehamna metamorphic dome (Morocco) in the context of the Alleghanian-Variscan orogeny: rehamna massif - moroccan variscan belt. Tectonics 33, 1154-1177.

Cornée, J.-J., 1982. Etude lithostratigraphique et tectono-métamorphique des Rehmana sud-orientales plissements et nappes contribution a la connaissance de la chaîne hercynienne en meseta marocaine. Univérsité de droit, d'économie et des sciences d'Aix-Marseille, Faculté des Sciences et Techniques de St.Jérôme.

Cornée, J.-J., Costagliola, C., Leglise, H., Willefert, S., Destombes, J., 1985. Précisions stratigraphiques sur l'Ordovicien supérieur et le Silurien du synclinal d 'Oulad Abbou, Meseta, marocaine occidentale. Manifestations volcaniques au Silurien. Ann. Soc. géol. Nord, Lille, CIV, 141-146.

Corsini, M., Muller, J., Cornée, J.-J., Diot, H., 1988. Découverte de la série basale du Cambrien et de son substratum dans les Rehamna centraux, hautfond au Cambrien (Méséta marocaine). Prémices de l'orogenèse hercynienne. Comptes Rendus de l'académie Des Sciences, Paris, 306, 63-68.

Debeglia, N., 2005. Estimation de la direction d'aimantation pour une réduction au pôle optimale du champ magnétique. BRGM/RP-54059-FR 34. 
Delchini, S., Lahfid, A., Lacroix, B., Baudin, T., Hoepffner, C., Guerrot, C., Lach, P., Saddiqi, O., Ramboz, C., 2018. The Geological Evolution of the Variscan Jebilet Massif, Morocco, Inferred from New Structural and Geochronological Analyses. Tectonics 2018TC005002.

Destombes, J., Guézou, J.C., Hoepffner, C., Jenny, P., Piqué, A., Michard, A., 1982. Le Primaire du massif des Rehamna s.s; problèmes de stratigraphie de séries méamorphiques, in Michard A. (Ed.), Le massif Paléozoique des Rehamna (Maroc). Notes et Mém. Serv. Géol. Maroc 303, 35-70.

Diot, H., 1989. Mise en place des granitoides hercyniens de la meseta marocaine. Thèse de Doctorat. Université Paul Sabatier. Faculté des Sciences de la Terre. Toulouse.

El Attari, A., 2001. Etude lithostratigraphique et tectonique des terrains paléozoiques du môle côtiér (meseta occidentale, Maroc). Thése de Doctorat. Universite Mohammed V-Agdal. Faculté des Sciences de Rabat.

El Gout, R., Khattach, D., Houari, M.R., 2009. Etude gravimétrique du flanc nord des Béni Snassen (Maroc nordoriental) : implications structurales et hydrogéologiques. Bulletin de l'Institut Scientifique, section Sciences de la Terre 31, 61-75.

El Hadi, H., Tahiri, A., Simancas Cabrera, F., González Lodeiro, F., Azor Pérez, A., Jesús Martínez Poyatos, D., 2006. Un exemple de volcanisme calco-alcalin de type orogénique mis en place en contexte de rifting (Cambrien de l'oued Rhebar, Meseta occidentale, Maroc). Comptes Rendus Geoscience 338, 229-236.

El Kamel, F., 1987. Géologie du paléozoïque des Rehamna nord-orientaux, Maroc. Évolution sédimentaire et structuration hercynienne d'un bassin dévono-carbonifère. Sédimentation et déformation des molasses post-orogénique. Université Aix-Marseille III.

El Kamel, F., Muller, J., 1987. Sédimentation et tectonique dans le bassin molassique permo-carbonifère de Mechra ben Abbou (Rehamna). Bulletin de l'Institut Scientifique, Rabat 69-78.

El Kamel, F., Remmal, T., Mohsine, A., 1998. Mise en évidence d'un magmatisme alcalin d'intraplaque post-Calédonien dans le bassin silurien des Ouled Abbou (Meseta côtière, Maroc). C. R. Acad. Sci. Paris. Sciences de la terre et des planétes.327. 309 - 31.

El Kamel, F., El Hassani, A., Mohsine, A., Remmal, T., 2000. Contrôle tectonique de l'édification des récifs Dévonien moyen de Mechra ben Abbou (Rehamna, Maroc). Comptes Rendus de l'Académie des Sciences - Series IIA - Earth and Planetary Science 330, 67-74.

El Kamel, F., 2002. Sédimentologie, magmatisme pré-orogénique et structuration du Paléozoïque des Rehamna et d'Ouled Abbou (Meseta occidentale, Maroc). Thèse de Doctorat. Université Hassan II, Faculté des Sciences de Casablanca, Maroc.

El Kamel, F., El Hassani, A., 2006. Étapes de la structuration et de la sédimentation du bassin viséen de Mechra ben Abbou (Meseta occidentale marocaine). Geodiversitas 28, 14.

El Mahi, B., 1991. Evolution tectono-metamorphique hercynienne des Rehamna centraux. Exemple d'interaction entre metamorphisme et mise en place de leucogranites dans une zone de cisaillement intralithospherique : la zone de cisaillement de la meseta occidentale (z.c.m.o.). Thèse de Doctorat. Université Mohammed V. Faculté des Sciences de Rabat. Maroc.

El Mahi, B., Hoepffner, C., Zahraoui, M., Boushaba, A., 1999. L’évolution tectono-métamorphique de la zone hercynienne des Rehaman centraux (Maroc). Bulletin de l'Institut Scientifique, Rabat, (22) 41-57.

El Mahi, B., Zahraoui, M., Hoepffner, C., Boushaba, A., Meunier, A., Beaufort, D., 2000. Les veines synmétamorphiques de quartz à disthène: témoins d'un métamorphisme associé à l'amincissement post-orogénique (Meseta occidentale, Maroc) Kyanite-quartz synmetamorphic veins: Indicators of post-orogenic thinning and metamorphism (Western Meseta, Morocco). Pangea, 23. Hoepffner, C. (1974). Contribution à la géologie structurale des Rehamna (Meseta marocaine méridionale), Le matériel paléozoïque et son évolution hercynienne dans l'est du massif.

Essaifi, A., Potrel, A., Capdevila, R., Lagarde, J.-L., 2003. Datation U-Pb : âge de mise en place du magmatisme bimodal des Jebilet centrales (chaîne Varisque, Maroc). Implications géodynamiques. Comptes Rendus Geoscience, 335, 193-203.

Fairhead, J.D., Bennett, K.J., Gordon, D.R.H., Huang, D., 1994. Euler: Beyond the "Black Box," in: SEG Technical Program Expanded Abstracts 1994. Presented at the SEG Technical Program Expanded Abstracts 1994, Society of Exploration Geophysicists, 422-424.

Fourier, M., 1822. Théorie analytique de la chaleur, Jacques Gabay. ed. Libraires pour les mathématiques, l'architecture hydraulique et la marine, rue Jacob, $\mathrm{N}^{\circ} 24$. 
Gasquet, D., Stussi, J.-M., Nachit, assane, 1996. Les granitoïdes hercyniens du Maroc dans le cadre de l'évolution géodynamique régionale. Bull. Soc. géol. France 167, 517-528.

Gigout, M., 1951. Etudes géologiques sur la Méséta marocaine occidentale (arrière-pays de Casablanca, Mazagan et Safi). Thèse de Doctorat. Universite de Paris.

Haïmeur, J., Hassani, I.-E.E.A.E., 2005. Rôle du brassage et du stockage magmatique dans l'homogénéisation des granitoïdes calco-alcalins: Cas du pluton composite de Zaër (Maroc central). Eclogae geologicae Helvetiae 98, 219-236.

Hoepffner, C., 1974. Contribution à la géologie structurale des Rehamna (Meseta marocaine méridionale), Le matériel paléozoïque et son évolution hercynienne dans l'est du massif.

Hoepffner, C., Jeannette, D., Jenny, P., Michard, A., Pique, A., 1975. Relations entre une tectonique de decrochement et un metamorphisme a disthene dans le massif hercynien des Rehamna (Maroc). Bulletin de la Societe Geologique de France S7-XVII, 421-429.

Hoepffner, C., Jenny, P., Piqué, A., Michard, A., 1982. Le métamorphisme hercynien dans le massif des Rehamna. Notes et Mémoires Service Géologique Maroc. Rabat, 303, 130-150.

Hoepffner, C., Soulaimani, A., Piqué, A., 2005. The Moroccan Hercynides. Journal of African Earth Sciences, 43(1-3), 144-165.

Hoepffner, C., Houari, M.R., Bouabdelli, M., 2006. Tectonics of the North African Variscides (Morocco, western Algeria): an outline. Comptes Rendus Geoscience 338, 25-40.

Hoepffner, C., Saddiqi, O., Michard, A., 2011. Volume 8, in: Circuit C14, La Meseta Sud-Occidentale In: Nouveaux Guides Géologiques et Miniers Du Maroc., Notes \& Mém. Serv. Géol. Maroc, n 563, 51-70.

Hoepffner, C., Ouanaimi, H., Michard, A., 2017. La Meseta, un terrain vagabond ou la marge fragmentée de l'Anti-Atlas, Bulltein Society geologist, France, 194, 19-24.

Hollard, H., Michard, A., Jenny, P., Hoepffner, C., Willefert, S., 1982. Stratigraphie du Primaire de Mechra ben Abbou. In Michard A. (coord.), Le massif paléozoique des Rehamna (Maroc). Stratigraphie, tectonique et pétrogenèse d'un segment de la chaîne varisque. Notes Mém. Serv. Géol. Maroc 303, 13-34.

Ivan, M., 1986. On the upward continuation of potential field data between irregular surfaces*. Geophysical Prospecting 34, 735-742.

Jarni, A., Jaffal, M., Mouguina, E.M., Maacha, L., En-Aciri, A., Outhounjite, M., Ouadjou, A., Zouhair, M., Radnaoui, A., Saddiqi, O., 2015. Les anomalies magnétiques de la province métallogénique des Jebilets-Guemassa (Maroc hercynien): Etat des connaissances et problématique liée à l'exploration minière. International Journal of Innovation and Applied Studies, 12 (2), 491-504.

Kharbouch, F., 1994. Les laves dévono-dinantiennes de la Meseta marocaine : étude pétro-géochimique et implications géodynamiques. Thèse de Doctorat. Université de Bretagne occidentale.

Kholaiq, M., 2017. Tectonique hercynienne et pétro-géochimie du magmatisme acido-basique du massif des Rehamna (Meseta Occidentale-Maroc). Thèse de Doctorat. Université Hassan II, Faculté des Sciences Ben M'sik. Casablanca.

Letsch, D., el Houicha, M., von Quadt, A., Winkler, W., 2018. A missing link in the peri-Gondwanan terrane collage: the Precambrian basement of the Moroccan Meseta and its lower Paleozoic cover. Canadian Journal of Earth Sciences, 55(1), 33-51.

Mayol, S., Muller, J., 1985. Mise en évidence d'une unité allochtone hercynienne précoce (antéschisteuse) dans les Jebilet occidentales (Maroc). Etude de la structuration de la zone de contact. CR. Acad. Sei., Paris 300, 369-372.

Mekonnen, T.K., 2004. Interpretation and Geodatabase of Dukes using Aeromagnetic data of Zimbabwe and Mozambique. Thesis, International Institute for Geoinformation science and Earth Observation, Enschede, the Netherlnds. Retrieved from Retrieved from http://www.slideserve.com/phila/partners.

Michard, A., 1982. Le massif paléozoïque des Rehamna (Maroc) : stratigraphie, tectonique et pétrogenèse d'un segment de la chaîne varisque. Notes Mém. Serv. géol. Maroc, Rabat, 303, 180 pp.

Michard, A., Saddiqi, O., Chalouan, A., De Lamotte, F. (Eds.), 2008. Continental evolution: the geology of Morocco: structure, stratigraphy, and tectonics of the Africa-Atlantic-Mediterranean triple junction, Lecture notes in earth sciences. Springer, Berlin.

Michard, A., Soulaimani, A., Hoepffner, C., Ouanaimi, H., Baidder, L., Rjimati, E.C., Saddiqi, O., 2010. The South-Western Branch of the Variscan Belt: Evidence from Morocco. Tectonophysics, 492, 1-24. 
Muller, J., Cornée, J.-J., El Kamel, F., 1991. Evolution tectono-sédimentaire d'un bassin molassique postorogénique: l'exemple des séries conglomératiques stephano-triasiques de Mechra ben Abbou, Rehamna, Maroc. Géologie Méditerranéenne, 18, 109-122.

Mushayandebvu, M.F., van Driel, P., Reid, A.B., Fairhead, J.D., 2001. Magnetic source parameters of two-dimensional structures using extended Euler deconvolution. Geophysics, 66, 814-823.

Nshimiyimana, Essarraj, Hibti, Boulvais, Boyce, Marignac, Maacha, 2018. The Koudia El Hamra Ag-Pb-Zn deposit, Jebilet, Morocco: Mineralogy and ore fluid characterization Félix Nshimiyimana, Samira Essarraj, Mohamed Hibti, Philippe Boulvais, Adrian Boyce, Christian Marignac, Lhou Maacha. Journal of African Earth Sciences.

Ouali, H., Briand, B., Bouchardon, J.-L., Capiez, P., 2003. Le volcanisme cambrien du Maroc central: implications géodynamiques. Comptes Rendus Geoscience, 335, 425-433.

Oukassou, M., 2018. Mise en évidence ichnologique des Xiphosures du Jurassique au Maroc: Contexte géologique, paléoenvironmental et paléobiogéographique. Thèse de Doctorat. Université Hassan II. Faculté des Sciences Ben M'sik. Maroc.

Pereira, M.F., El Houicha, M., Chichorro, M., Armstrong, R., Jouhari, A., El Attari, A., Ennih, N., Silva, J.B., 2015. Evidence of a Paleoproterozoic basement in the Moroccan Variscan Belt (Rehamna Massif, Western Meseta). Precambrian Research 268, 61-73.

Rais-Assa, R., 1984. Etude géologique de la partie occidentale du massif hercynien des Rehamna septentrionales (Meseta marocaine). Lithostratigraphie, plissements et métamorphisme, chevauchements et nappes. Thèse. Université de droit, d'économie et des sciences d'Aix-Marseille, Faculté des Sciences et Techniques de St.Jérôme.

Razin, P., Baudin, T., Chevremont, P., Andries, D., Youbi, N., Hoepffner, C., Thieblemont, D., Chihani, E.-M., 2003. Carte géologique du maroc au 1/50 000 feuille de jebel kharrou. Ministère de l'Energie et Mines. direction de la Géologie. Edition du service géologique du Maroc. Notes et Mémoires.

Reid, A.B., Allsop, A.B., Granser, H., Millett, A.J., Somerton, I.W., 1990. Magnetic interpretation in three dimensions using Euler deconvolution. Geophysics, 55, 80-91.

Remmal, T., El Kamel, F., Mohsine, A., 1997. Le bassin viséen de Mechraâ Ben Abbou (Meseta occidentale, Maroc): une structure sur décrochement $\mathrm{N} 80^{\circ}$ associée à un magmatisme tholéitique d'intraplaque. Géologie Méditerranéenne 24, 225-239.

Saber, N., 1989. Evolution sédimentaire du bassin Devono-Dinantien de Mechraa Ben Abbou (Rehamna septentrionaux). (Thèse de 3ème cycles). Univ Caddi Ayyad, fac Sci Marrakech.

Saidi, A., Tahiri, A., Ait Brahim, L., Saidi, M., 2002. États de contraintes et mécanismes d'ouverture et de fermeture des bassins permiens du Maroc hercynien. L'exemple des bassins des Jebilet et des Réhamna. Comptes Rendus Geoscience 334, 221-226.

Sailhac, P., 1999. Analyse multiéchelle et inversion de données géophysiques en Guyane Française: (in French): (Thèse de Doctorat).

Salvan, H.M., 1985. Particularités de répartition stratigraphique des dépôts phosphatés de la Mésogée et de la bordure atlantique du continent africain. Nouvelles possibilités d'interprétation. Sciences Géologiques 93-98.

Silva, J.B.C., Barbosa, V.C.F., 2003. 3D Euler deconvolution: Theoretical basis for automatically selecting good solutions. GEOPHYSICS 68, 1962-1968.

Tahiri, A., Simancas, J.F., Azor, A., Galindo-Zaldívar, J., González Lodeiro, F., El Hadi, H., Martínez Poyatos, D., Ruiz-Constán, A., 2007. Emplacement of ellipsoid-shaped (diapiric?) granite: Structural and gravimetric analysis of the Oulmès granite (Variscan Meseta, Morocco). Journal of African Earth Sciences, 48, 301-313.

Wernert, P., Schulmann, K., Chopin, F., Štípská, P., Bosch, D., El Houicha, M., 2016. Tectonometamorphic evolution of an intracontinental orogeny inferred from P-T-t-d paths of the metapelites from the Rehamna massif (Morocco). Journal of Metamorphic Geology. 34, 917-940.

Yahyaoui, L., Essaifi, A., 2011. Massif des Jbilet (meseta sud-occidentale), in : Nouveaux guides géologiques et miniers du Maroc., Notes et Mémoire Sérvice Géologique. Maroc, 71-82. 